\title{
TAMAN REKREASI OLAHRAGA DI SUNTER PERMAI
}

\author{
Dennis Dharmadi ${ }^{1)}$, Martin Halim ${ }^{2)}$ \\ 1)Program Studi S1 Arsitektur, Fakultas Teknik, Universitas Tarumanagara, dharmadidennis@gmail.com \\ 2) Program Studi S1 Arsitektur, Fakultas Teknik, Universitas Tarumanagara, Martinhalim90@gmail.com
}

\begin{abstract}
Abstrak
Kesehatan merupakan salah satu masalah terbesar yang dihadapi Jakarta saat ini. Bedasarkan Riset Kesehatan Dasar, masalah kesehatan tertinggi yaitu penyakit tidak menular dan penyakit mental atau stress. Penyakit yang mengalami kenaikan pesat mulai dari hipertensi, diabetes, ginjal, stroke, dan penyakit mental atau stress. Penyakit-penyakit tersebut dapat diselesaikan dengan berbagai solusi yang melibatkan kegiatan berolahraga, aktif berkomunikasi dengan sesama, konsumsi makanan sehat, melakukan pola hidup sehat, dan berkonsultasi pada ahlinya. Menerapkan berolahraga terbuka dan gaya olahraga baru dapat mengundang minat masyarakat generasi $Z$ dan milenial untuk berolahraga. Sunter Permai Sports Park hadir sebagai sarana berolahraga bagi masyarakat Jakarta, khususnya masyarakat Jakarta Utara. Sports Park yang dimaksud sendiri merujuk pada kegiatan olahraga yang menghubungkan olahraga dengan alam sekitar dan komunikasi antar pengguna didalamnya. Energetic sendiri berarti pengguna didalam taman ini diharuskan berenergi dan melakukan aktivitas olahraga atau berinteraksi dengan sesama. Metode perancangan yang digunakan sendiri adalah biophilic design concept, yaitu konsep yang memasukan alam kedalam program ruang dengan kegiatan olahraga didalam proyeknya. Park sendiri memiliki arti tempat berkumpul masyarakat suatu daerah dengan bentuk taman. Program utama dalam proyek ini yaitu olahraga dengan tema kekinian dan olahraga yang disukai masyarakat kelurahan Sunter Agung. Selain program olahraga, program yang ditawarkan juga ada kuliner makanan sehat dan konsultasi psikologis, serta meditasi, program kuliner makanan sehat ini ditujukan untuk memberi pengetahuan bagi masyarakat untuk memulai pola hidup sehat dengan konsumsi makanan sehat.
\end{abstract}

\section{Kata kunci: Interaksi; Kekinian; Kesehatan}

\begin{abstract}
Health has been one of the greatest problem that Jakarta faced for years. According to RisKesDas (Basic Health Research) 2018, health issue in Jakarta has been increasing drastically in physical health and mental health or as we call it stress issue. Those health issue share the same solution, as doing routine exercises or sports, healthy lifestyle, communicating with each other, or consultate with other person. Open sports and new sports can be an invitation for today's millennials and generation $Z$ to do sports and starting healthy lifestyle. Sunter Permai Sports Park can be a new sports facility for people in Jakarta. Sports Park here means that everyone in the facility has to be energetic, doing sports, or communicating with each other, the vibes is sporty and playful. Sunter Permai Sports Park is using biophilic as design principal, by using natural materials, as in vegetations, rocks and stones, pond and waterfall. The highlighted programs in this project are futuristic or esports, and sports that are liked by Sunter Agung neighborhoods. Aside sport activities, there are healthy culinary foodstreet, health consultation, yoga and meditation. Healthy culinary foods are dedicated to educate people to start a healthy lifestyle by consuming healthy foods.
\end{abstract}

Keywords: Health; Interaction; Up-to-date 


\section{PENDAHULUAN}

\section{Latar Belakang}

Jakarta merupakan salah satu kota dengan kepadatan penduduk tertinggi di Indonesia. Bedasarkan riset Badan Pusat Statistik tahun 2019, 57\% penduduk dari Indonesia terdapat di Pulau Jawa. Survei penduduk Antar Sensus tahun 2019 (SUPAS) memproyeksikan bertambahnya penduduk Jakarta sebanyak 72ribu jiwa, mencapai 10,57juta jiwa. Laporan Badan Pusat Statistik (BPS) dan Bappenas menyebutkan jumlah ini naik 0,7\% dari tahun sebelumnya yang sebanyak 10.504.100 jiwa. Pada kesempatan program ASEAN Leader Programme 2018 lalu, Anies Baswedan selaku Gubernur DKI Jakarta, mengatakan bahwa Jakarta menghadapi 5 masalah utama yaitu biaya hidup, akses air bersih, lapangan pekerjaan atau pengangguran, lalu pendidikan dan kesehatan. Sport Park sebagai fasilitas berkumpul dan berolahraga bagi masyarakat hadir sebagai tempat untuk menjawab masalah kesehatan baik dari kesehatan fisik, mental, dan membangun pola hidup sehat.

\section{Rumusan Permasalahan}

Menurut Kementrian Kesehatan melalui RisKesDas tahun 2018, masalah kesehatan yang dihadapi Jakarta yaitu penyakit menular, tidak menular, masalah gizi, dan penyakit mental. Penyakit menular dan masalah gizi mengalami penurunan angka yang cukup baik, sedangkan penyakit tidak menular mengalami kenaikan cukup tinggi, seperti kanker dari 1,2\% menjadi $1,8 \%$, stroke dari $1,4 \%$ menjadi $7 \%$, penyakit ginjal dari $2 \%$ menjadi $3,8 \%$, diabetes dari $6,9 \%$ menjadi $8,5 \%$, dan hipertensi dari $25,8 \%$ menjadi $34,1 \%$. Penyakit mental yang dimaksud dengan stress mengalami kenaikan drastic dari 1,3\% menjadi $7 \%$. Ada 2 jenis stress yaitu Eustress dan Distress, Eustress merupakan stress yang positif, menghasilkan respon yang sehat dan memberi mental konstruktif. Distress merupakan kebalikan dari Eustress dimana merupakan stress negatif yang memberi respon tidak sehat, dan mengacaukan mental. Sebagian besar orang menggambarkan stress sebagai tekanan yang dialami manusia dengan banyaknya pekerjaan yang melelahkan, atau situasi yang membuat seseorang merasa jenuh. Stress yang berkelebihan dapat membuat seseorang Lelah fisik, tidak dapat berpikir jernih, tidak fokus, dan bahkan menimbulkan penyakit. Bila stress yang berkelebihan tersebut menumpuk, seseorang dapat mengalami gangguan mental.

\section{Tujuan}

Arsitektur dapat menjadi solusi bagi masalah kesehatan ini, dengan menyediakan tempat yang menampung masyarakat untuk membantu mengurangi tensi yang dialami masyarakat dengan berinteraksi satu sama lain, melepas stress sejenak, sekaligus menjadi tempat untuk mengolah fisik dengan baik. Tempat ini juga diharapkan dapat menarik masyarakat untuk membangun fisik dan menciptakan kawasan yang lebih sehat.

\section{KAJIAN LITERATUR}

Dalam perancangan, teori-teori dan konsep perancangan dikaji untuk memahami open architecture, third place, dan kegiatan olahraga yang merupakan program utama dalam proyek ini. Kajian teori dilakukan untuk menjawab masalah yang ada di masyarakat dan menghasilkan sebuah tempat bagi masyarakat untuk berkumpul, berinteraksi, juga melakukan kegiatan berolahraga yang meningkatkan kesehatan masyarakat secara fisik dan mental.

\section{Third Place Architecture}

Third place architecture, atau ruang ketiga memiliki peruntukan sebagai wadah yang mempertemukan masyarakat untuk bersosialisasi satu sama lain. Sebagai tempat untuk "relaksasi" atau tempat untuk berekspresi terlepas dari tempat pertama yaitu rumah dan tempat kedua yaitu tempat kita bekerja. "Third place" hadir sebagai tempat yang bersifat netral, dapat diakses dan digunakan oleh siapapun. Semua orang dapat berekspresi dari kalangan 
manapun tanpa memandang latar belakang atau budaya seseorang. "Third place" juga merupakan tempat yang memiliki ragam yang bermacam-macam sesuai dengan kehidupan dan latar belakang kawasan tertentu. Masalah dari third place yaitu masyarakat kota yang sibuk dengan pekerjaannya masing masing, ditambah dengan masalah waktu untuk meluangkan dan melepas stres dengan melakukan aktifitas dengan sesama.

\section{Karakteristik Third Place Architecture}

Menurut Ray Oldenburg - the great good place,1997, sebuah third place memiliki karakteristik sebagai berikut :

a. Neutral Third place dapat berperan sebagai tempat netral bagi beragam masyarakat, setiap orang bebas untuk memasuki third place.

b. Level Sebuah third place tidak bersifat eksklusif, tempat tersebut tidak memandang latar belakang masyarakat seperti kedudukan atau pekerjaan, ras atau kebudayaan.

c. Conversation Komunikasi merupakan aktivitas utama dalam sebuah third place, dalam third place, seseorang bebas mengemukakan pendapat dan berbagi pikiran.

d. Accessible Third place haruslah dapat dicapai, tidak bersifat terkurung atau dibatasi.

e. Regulars Sebuah third place memiliki karakter yang kuat dari pengunjungnya sendiri, dan menyambut kedatangan semua orang.

f. Unpretention Third place memiliki bentuk fisik sederhana, yang memberi kenyamanan dan tidak memberi kesan eksklusif.

g. Playful Mood Suasana yang diciptakan dalam third place berupa suasana yang menyenangkan, yang dapat menarik pengunjung.

h. Home far from Home Rumah merupakan tempat kita memulai kepergian kita dan menjadi tempat yang menyambut kedatangan kita, rumah menjadi akar bagi kita semua.(David Seamon,1979). Third place juga menawarkan tempat yang menerima semua orang dengan keramahan, dan perhatian bersama.

\section{Olahraga}

Menurut kamus Oxford bahasa Inggris, "sport (/spo:t/) is an activity involving physical exertion and skill in which an individual or team competes against another or others for entertainment", yang dapat diterjemahkan sebagai aktifitas yang melibatkan kegiatan fisik dan kemampuan seseorang atau berkelompok dalam berkompetisi dengan sesama untuk hiburan. Sedangkan dalam kamus bahasa Indonesia (KBBI), olahraga (/olah.ra.ga/) berarti gerak badan untuk menguatkan dan menyehatkan tubuh. Dari kedua statement kamus bahasa Inggris dan Indonesia, disimpulkan bahwa olahraga merupakan kegiatan yang melibatkan gerak fisik dan dilakukan oleh perorangan ataupun kelompok, dengan tujuan:
a. Menyehatkan tubuh
b. Menguatkan tubuh
c. Mencari kesenangan, serta
d. Tujuan hiburan (entertainment).

\section{Olahraga E-Sports}

Olahraga E-Sports menurut Evolution Championship Series merupakan kegiatan yang melibatkan kemampuan seseorang atau kelompok untuk berkompetisi dalam suatu permainan. Menurut data riset Global Web Index, terlihat ketertarikan generasi milenial dan generasi Z pada E-Sports atau game. Adapun bedasarkan PewResearch yang mendefinisikan milenial sebagai orang yang lahir dari 1981-1996 dan generasi Z sebagai orang yang lahir pada 1997-2012. Di Indonesia, terdapat IeSPA (Indonesia eSports Association) yang merupakan badan E-Sports Indonesia, IeSPA juga mengatakan bahwa E-Sports merupakan kompetisi yang tidak melakukan kontak fisik namun mementingkan strategi pertandingan melalui komputer dengan gamers lain secara online dengan atau tanpa bertatap muka. Pada hal ini, leSPA merupakan bagian dari FORMI atau Federasi Olahraga Rekreasi Masyarakat Indonesia, yang diresmikan oleh 
Kemenpora. Olahraga E-Sports yang merupakan salah satu kegiatan yang banyak diminati milenial juga memiliki game yang memadukan olahraga secara fisikal dengan teknologi Augmented Reality yang menjadikan kegiatan fisik seperti berjalan atau berlari menjadi sebuah game atau E-sports, contohnya Pokemon GO. Bedasarkan data NewZoo 2016, game Pokemon GO ini diunduh sebanyak 800juta device pada awal rilis hanya dalam satu bulan pertama. Hingga tahun 2019 terakhir, game ini masih memiliki pemain aktif sebanyak 187juta menurut data NewZoo 2019. Game yang melibatkan olahraga dengan basis teknologi AR ini sendiri di Jakarta memiliki peminat yang cukup banyak, dengan kurang lebih 6.500 pemain aktif di seluruh Jakarta (komunitas Pokemon GO Jakarta), dan beberapa komunitas lainnya.

\section{Stress Reliefing}

Munculnya berbagai masalah di perkotaan menyebabkan orang yang tinggal di perkotaan mengalami stres. Banyak masyarakat perkotaan dari berbagai kalangan mengeluh dengan kondisi kota saat ini, mulai dari keramaian, kepadatan, dan suasana kota. Hingga kini masyarakat perkotaan tidak memiliki kualitas hidup yang baik dan sesuai kebutuhan. Menurut riset LSE Cities, dibandingkan dengan kondisi pedesaan, kondisi perkotaan memiliki kondisi psikis dan kesehatan yang tidak lebih baik dari kondisi pedesaan. Kondisi padat di perkotaan dapat diseimbangkan salah satunya dengan ruang terbuka hijau. Ruang terbuka hijau yang menyediakan ruang untuk beraktifitas, untuk merelaksasi diri, secara fisik dan psikis, dan berfungsi untuk komunikasi antar pengguna.

Bedasarkan Buku "The Nature Fix" (2017) oleh Florence Williams, terdapat sebuah penelitian terkait manfaat melakukan aktifitas di ruang terbuka hijau, dan berbicara dengan sesama di taman dalam jangka waktu 15 menit dapat membuat suasana lebih bahagia dan mengurangi stres. Penelitian tersebut juga mengatakan dengan menghabiskan waktu di ruang terbuka hijau dengan melakukan aktifitas (berjalan, bercengkerama, dll) dapat mengurangi aliran darah ke otak yang terasosiasi dengan pemikiran zat stressor negatif, sehingga membantu kita untuk dapat berpikir secara positif. Buku ini juga mengatakan bahwa saat berada di ruang terbuka hijau, memori dan kreativitas kita juga cenderung meningkat. Hal ini juga didukung oleh Dr. Juneman Abraham, S.Psi., seorang ahli psikologi sosial, yang mengatakan bahwa beraktivitas di ruang terbuka hijau merupakan cara yang efektif untuk meningkatkan kesehatan mental.

\section{Hubungan Indera Manusia dan Ruangan}

Bedasarkan International Journal of Interdisciplinary Research and Innovations, Vol. 2, Issue 4, pp: (139-156), seseorang dapat merasakan healing space untuk mengurangi stres atau penyakit mental yang dialami dengan menggunakan kelima inderanya, yaitu penglihatan, penciuman, pendengaran, perasa, dan peraba. Dari riset tersebut juga dikatakan bahwa dengan kemajuan teknologi yang dapat diimplementasikan dalam ruangan dapat membantu pengguna ruang untuk merasakan kualitas ruang dan elemennya yang akan membantu dalam pemulihan stress dan mendukung untuk beraktifitas.

\section{Penglihatan}

Indra penglihatan adalah salah satu indera yang paling penting dalam merasakan elemen ruang, indera penglihatan berperan atas cahaya, warna, pola, bentuk, serta tekstur dalam ruang. Menurut riset International Journal of Interdisciplinary, ruang yang indah secara visual, dengan pencahayaan, warna, bentuk, tekstur yang tepat dapat memberi suasana positif yang berpengaruh pada pikiran atau psikis pengguna ruang.

\section{Pendengaran}

Suara dalam ruangan berperan sebagai stimulus yang ampuh, membangkitkan perasaan yang menyenangkan dan memberi respon dari stres fisikal dan psikis. Suara dengan intensitas tinggi, 
sebaliknya dapat menimbulkan perasaan jenuh atau menimbulkan stres. Riset yang dilakukan oleh Soundscape menunjukan bahwa suara yang dianggap menyenangkan yaitu suara alam.

\section{Penciuman}

Odor atau bau merupakan salah satu unsur yang paling cepat dalam mempengaruhi respon manusia. Stimulasi yang disampaikan oleh bau memberi respon yang berbeda oleh setiap orang (Luke Vorstermans, 2007). Bau memiliki efek yang kuat pada perilaku seseorang. Bau tertentu dapat memberi efek positif dan mengangkat gairah atau semangat seseorang, seperti bau kopi, roti, atau makanan kesukaan. Sebuah wangi parfum atau bau alam dapat mengangkat keintiman dan asmara, atau memberi respon rileks, tenang, dan membuat pengguna merasa di dalam rumah.

\section{Bentuk}

Bedasarkan riset International Journal of Interdisciplinary Research and Innovations, Manusia menunjukkan respon lebih positif secara fisik dan psikis pada struktur bentuk yang kompleks namun terorganisir, dibanding lingkungan dengan bentuk yang polos (Salingaros, 2006). Respon yang ditunjukkan ini membuktikan bahwa bentuk ruangan atau lingkungan yang dibangun juga memiliki peran sama seperti alam.

\section{Biophilic Design}

Konsep Biophilic design merupakan salah satu metode desain yang dapat membantu kehidupan urban yang padat dan mereduksi stress pada individu. Bedasarkan TERRAPIN Bright Green dalam jurnal yang berjudul Patterns of Biophilic Design, terdapat 14 pola yang dapat diterapkan pada objek rancangan. Dari 14 pola tersebut, dikelompokkan menjadi 3 yaitu nature in the space, natural analogues, dan nature of the space.

a. Nature in the Space Pattern

Membahas tentang kehadiran alam secara langsung pada suatu tempat. Kehadiran alam tersebut termasuk kehidupan air, tanaman, angin, suara alam, aroma, atau elemen lainnya.

b. Natural Analogues Pattern

Membahas tentang kehadiran alam yang tidak langsung pada suatu tempat. Berupa benda, bahan, warna, bentuk, atau pola yang dibuat pada alam. Kehadiran Natural Analogues Pattern berupa karya seni, ornamen, furnitur, dekorasi, atau tekstil yang ada pada perancangan.

c. Nature of the Space Pattern

Membahas tentang ruang yang ada di alam. Berupa ruang yang menggabungkan antara Nature in the Space Pattern dan Nature Analogues Pattern.

\section{METODE}

\section{Metode Pengumpulan Data}

Pengumpulan data dilakukan sebagai acuan dalam perancangan, yang diperoleh secara langsung dari lapangan, berupa analisis dan wawancara dari sumber di lapangan. Data yang didapat yaitu data primer dan sekunder, data primer berupa survey lapangan dan data sekunder merupakan data yang didapatkan dari artikel atau jurnal dari internet yang kemudian dikaji kembali.

\section{Data Primer}

Survey lapangan dilakukan langsung di lokasi dengan menganalisa mulai dari data-data yang membentuk ruang kota secara fisik dan aktivitas masyarakat di kawasan Sunter Agung. Tapak berletak di muka jalan Sunter Permai Raya, dan bersebelahan dengan tiga sekolah yaitu Sekolah Lentera Kasih, Kampus 17 Agustus, dan Sekolah IPEKA II. Selain dikelilingi sekolah, tapak juga berletak dilewati oleh masyarakat dari first place (rumah) dan second place(tempat bekerja). Terlihat juga jalan yang memiliki lebar kurang lebih $8 \mathrm{~m}$, dengan pedestrian depan tapak dengan 
kondisi kurang baik selebar $2 \mathrm{~m}$. Sekitar tapak memiliki keramaian yang cukup pada waktu pagi hingga sore hari, dan pada malam harinya jalanan berkesan sepi.

\section{Data Sekunder}

Data sekunder merupakan data yang didapat secara tidak langsung, penulis menggunakan data dari BPS DKI Jakarta, yang menunjukan fasilitas olahraga dan perkumpulan atau komunitas olahraga di kecamatan Tanjung Priok. Bedasarkan data BPS tahun 2019 tersebut, Kelurahan Sunter Agung memiliki fasilitas olahraga yang cukup dan menunjukkan minat tinggi di bidang olahraga, namun memiliki kekurangan tempat untuk berkumpulnya masyarakat sekitar untuk berkumpul sambil melakukan kegiatan berolahraga.
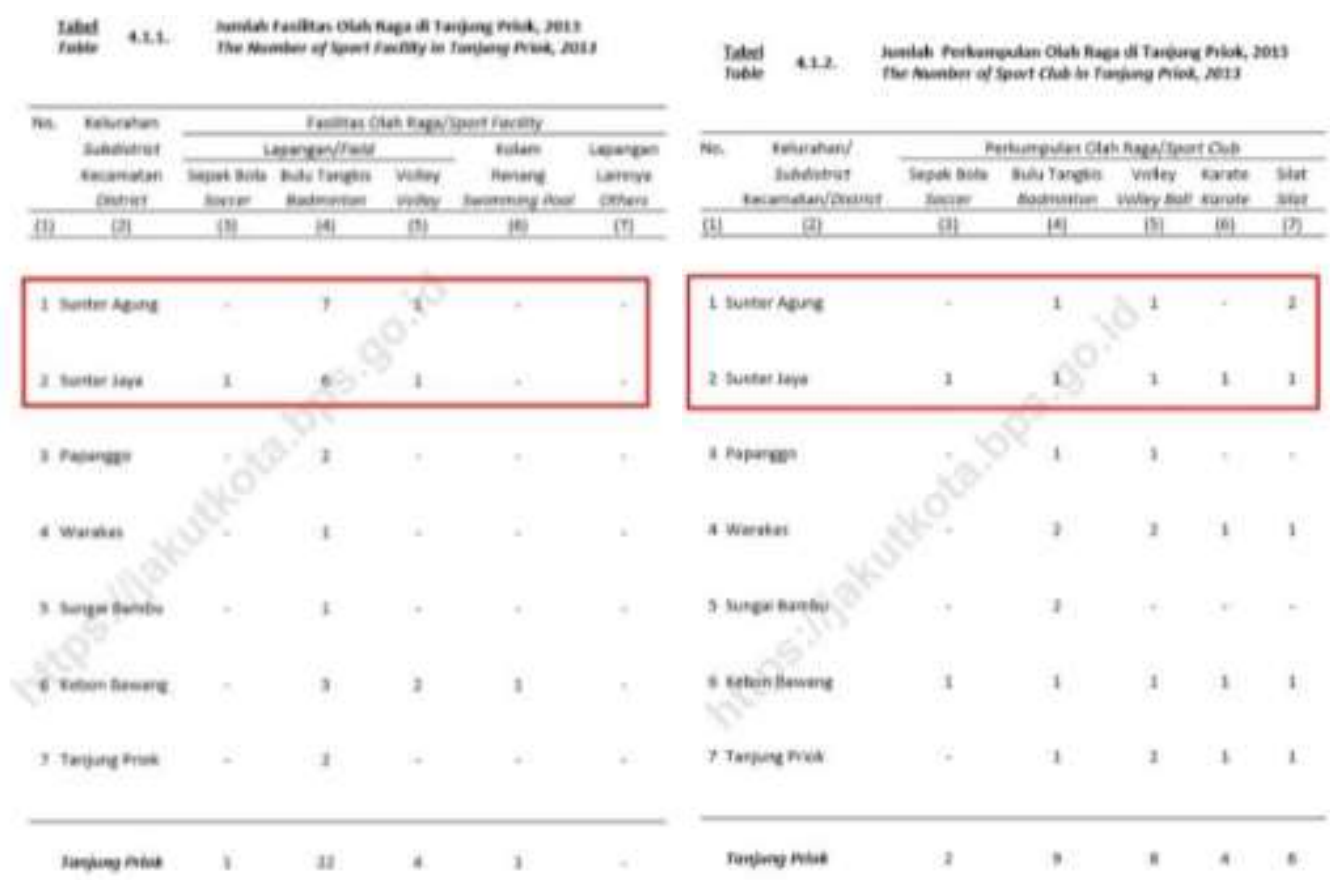

Gambar 1. Data Fasilitas dan perkumpulan olahraga di Tanjung Priok Sumber: BPS: Tanjung Priok dalam angka 2019

\section{Studi Preseden}

Untuk memperkuat proses perancangan, dilakukan studi preseden mengenai proyek-proyek serupa dengan proyek yang akan dirancang, 3 buah proyek dari luar negeri seperti RoteBro Sports Hall, Street Dome, Chungnam Sport Center, dan 2 proyek dalam negeri, GOR Brodjonegoro, dan Gelora Bung Karno.

\section{DISKUSI DAN HASIL}

\section{Analisis Tapak}

Tapak terpilih berletak di jalan Sunter Permai Raya, dengan luas 3468 meter persegi, dengan zonasi berwarna oranye yaitu zonasi campuran. Untuk peraturan yang berlaku sendiri yaitu KDB 50, KLB 2, KDH 30, dan Ketinggian bangunan 3 lapis. Tapak sendiri memiliki letak yang mudah diakses karena dilewati oleh transportasi umum atau pribadi, dan letaknya bersebelahan dengan sekolah Lentera Kasih dan kampus 17 Agustus 1945. 


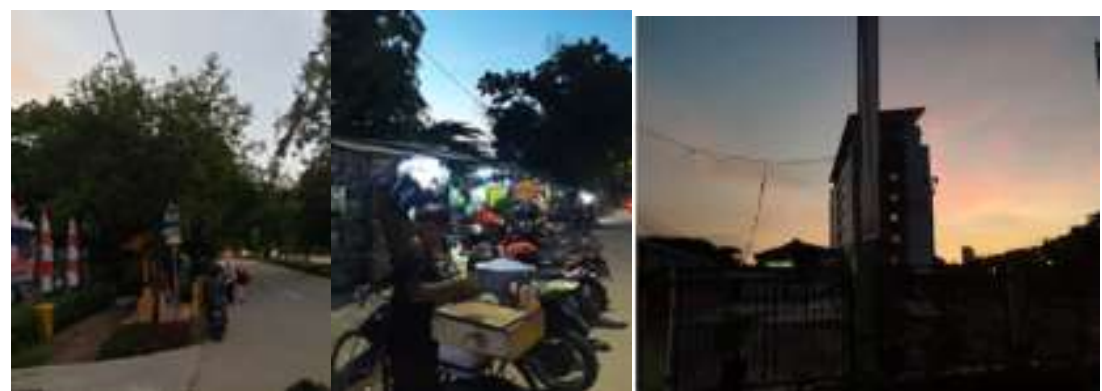

Gambar 2. Kondisi sekitar tapak, halte bus, kampus, dan PKL

Sumber: Penulis, 2020

\section{Analisis fungsi bangunan}

Sunter Permai Sports Park memiliki 3 program utama yaitu kegiatan olahraga fisikal, kegiatan olahraga relaksasi, dan kuliner sehat. Dimana ketiga program ini menjawab dari permasalahan kesehatan, yang bersifat rekreasi, kegiatan olahraga fisikal mulai dari street sports, olahraga badminton, gym, dan lain lain, sebagai penyelesaian masalah kesehatan dan kebugaran. Olahraga Relaksasi menjawab pada permasalahan penyakit mental dan kebugaran, dan kuliner makanan sehat menjawab pada pembentukan pola hidup sehat bagi masyarakat. Terdapat juga berbagai program penunjang yaitu fasilitas konsultasi kesehatan, area berkumpul, dan fitness check-in. fasilitas fasilitas pendukung ini juga memiliki suasana olahraga rekreasi.

\section{Programatik}

Program ruang dalam bangunan dikelompokan menjadi tiga yaitu kegiatan utama yang mencakup street sports, futuristic sports, relaxing sports, dan healthy food culinary. Program program ini dimaksudkan untuk menjawab masalah kesehatan masyarakat, mulai dari street sports yang mencakup kegiatan olahraga bergaya baru dan disukai oleh masyarakat, futuristic sports, merupakan olahraga dengan gaya futuristic yang berhubbungan dengan teknologi atau game, dimana olahraga ini menarik minat generasi milenial dan generasi $Z$ yang menyukai game atau e-sports. Relaxing Sports dan Healthy food culinary dibentuk untuk pengguna yang menyukai olahraga ringan dan ingin membentuk pola hidup sehat, dan kemunngkinan lebih diminati oleh pengguna dewasa.

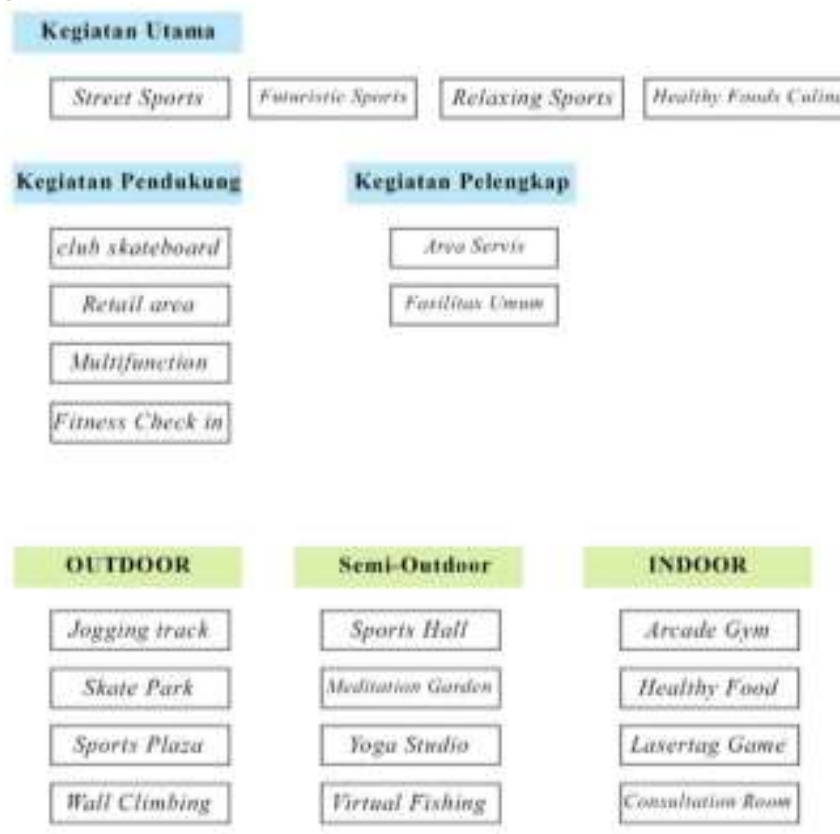

Gambar 3. Program Kegiatan

Sumber: Penulis, 2020 
Kegiatan pendukung seperti skateboarding area, yang berhubungan langsung dengan sportss plaza, merupakan tempat berolahraga yang terbuka yang juga berhubugnan dengan sports hall. Lalu ada area kegiatan indoor yaitu lasertag game yang berletak di basement, dimana ruang game ini memerlukan ruang leluasa tanpa melanggar batas KDB, ruang ini akan didesain dengan partisi-partisi yang memungkinkan pengguna untuk bermain game laser. Selain itu ada ruang arcade gym, dimana gym ini memiliki 2 suasana yang berbeda saat siang hari dan malam hari, saat siang hari, gym ini dapat digunakan seperti gym pada umumnya, saat malam hari, gym ini memiliki lampu LED warna warni yang memberi suasana game pada ruangan gym, dan memberi suasana ramai dari luar.

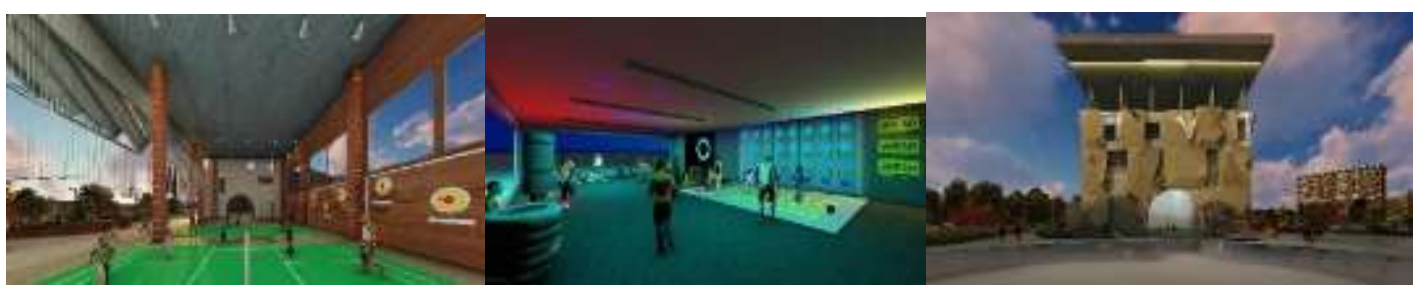

Gambar 4. Area olahraga indoor dan outdoor

Sumber: Penulis, 2020

Hasil organisasi ruang dilanjutkan dengan mengolah denah dengan standar ergonomis dan studi preseden proyek yang dikaji. Denah bangunan dirancang memiliki sirkulasi yang dinamis karena target utama dari proyek adalah masyarakat milenial. Konsep desain biophilic juga dimasukan kedalam bangunan, dimana pada teori tersebut, menghubungkan alam dengan bangunan, hal ini digambarkan dengan pengolahan bentuk bangunan dengan masuknya alam kedalam bangunan, dan pengolahan lanskap yang berhubungan dengan bangunan. Massa sendiri dibagi menjadi 3 Massa dimana setiap massa didesain berhubungan dengan lanskap agar pengguna dapat melakukan kegiatan olahraga sambil menikmati alam sekitar. Vegetasi lanskap diatur sesuai dengan mapping yang dirancang untuk tujuan kenyamanan pengunjung dan buffer panas serta kebisingan. Lanskap yang diolah ini dapat dijadikan sarana bagi pengunjung secara leluasa untuk menikmati suasana dan berkumpul dengan bersama. Data-data dari survey lapangan dikelompokan untuk dijadikan acuan dalam mendesain, hasil analisis tersebut kemudian di masukkan kedalam proses desain sebagai berikut :

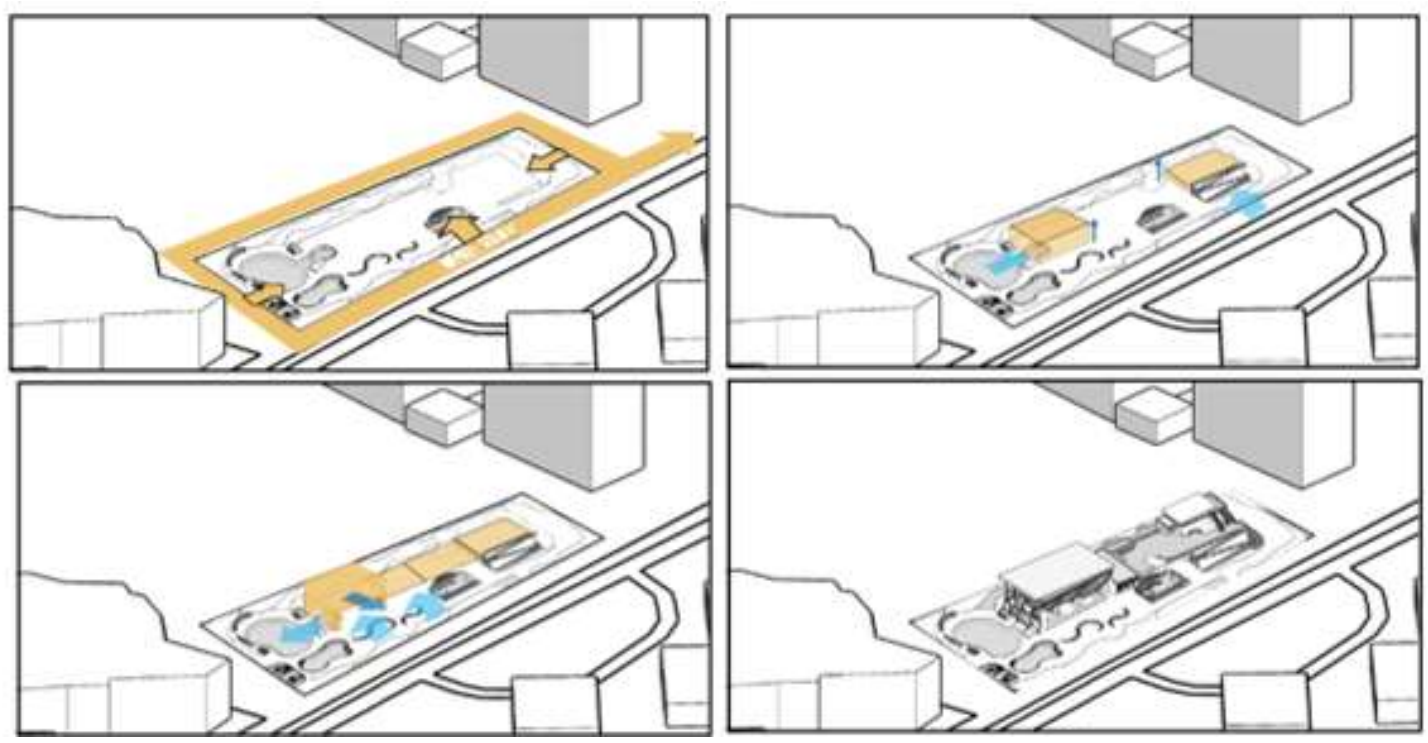

Gambar 5. Proses gubahan massa Sumber: Penulis, 2020 
a. Penyesuaian bentuk massa bangunan dengan bentuk tapak dengan aturan GSB yang berlaku yaitu $6 \mathrm{~m}$.

b. Mengangkat massa massa utama untuk memaksimalkan KB pada sebelah kiri dan kanan.

c. Massa diberi bukaan besar menyesuaikan dengan program ruang dan memberi kesan openess, juga pencahayaan alami yang cocok dengan konsep kegiatan berolahraga.

d. Sirkulasi dan hubuungan antar massa dibantu dengan penggunaan ramp dan tangga yang menghubungkan program kegiatan satu dan lainnya

e. Tahap pengolahan massa bedasarkan mapping menghasilkan bentuk olahan lingkungan yang memiliki bentuk mengacak dan memilliki alur melingkar.

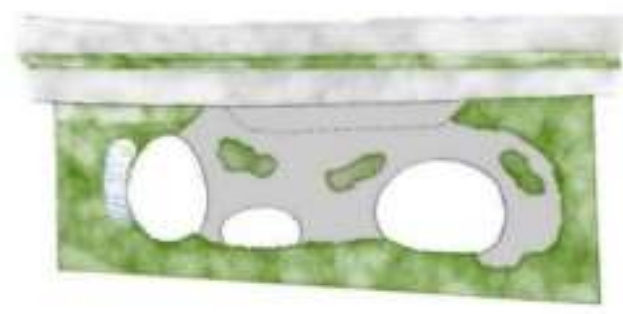

Gambar 6. Vegetation Mapping Sumber: Penulis, 2020

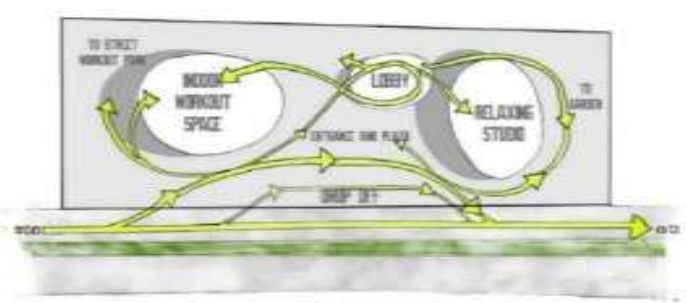

Gambar 7. User Circulation Mapping Sumber: Penulis, 2020

Melalui analisis dihasilkan gubahan massa akhir yang berasal dari proses survey dan penggunaan konsep biopilic. Gubahan massa lalu diberikan ruang sesuai dengan program ruang yang telah dirancang. Pemasukan ruang kedalam massa disusun secara horizontal dan vertikal, disesuaikan dengan eratnya hubungan antar kegiatan satu dan lainnya. Gubahan massa akhir dengan organisasi ruang yang berasal dari survey dan metode perancangan biophilic design ini dijadikan acuan.

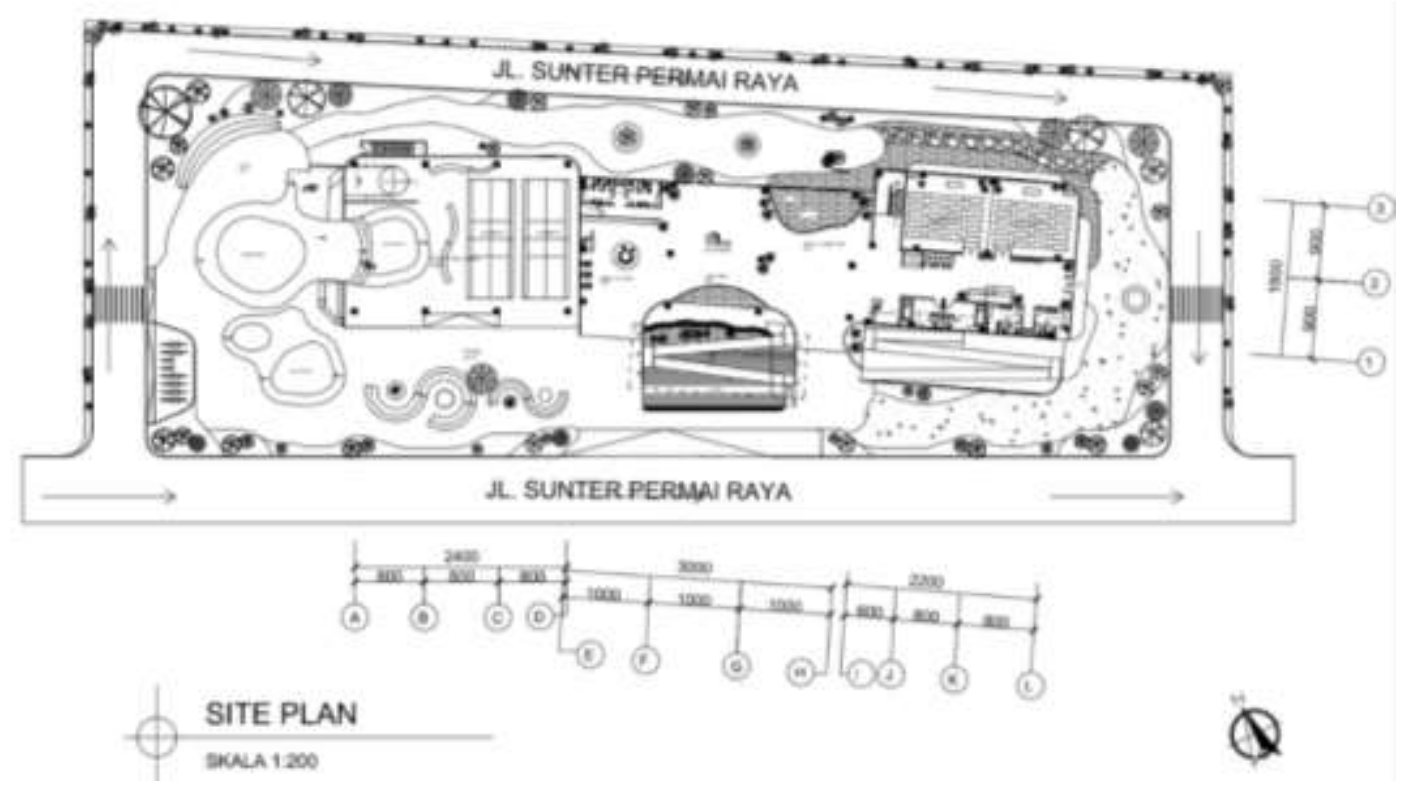

Gambar 8. Site Plan

Sumber: Penulis, 2020 


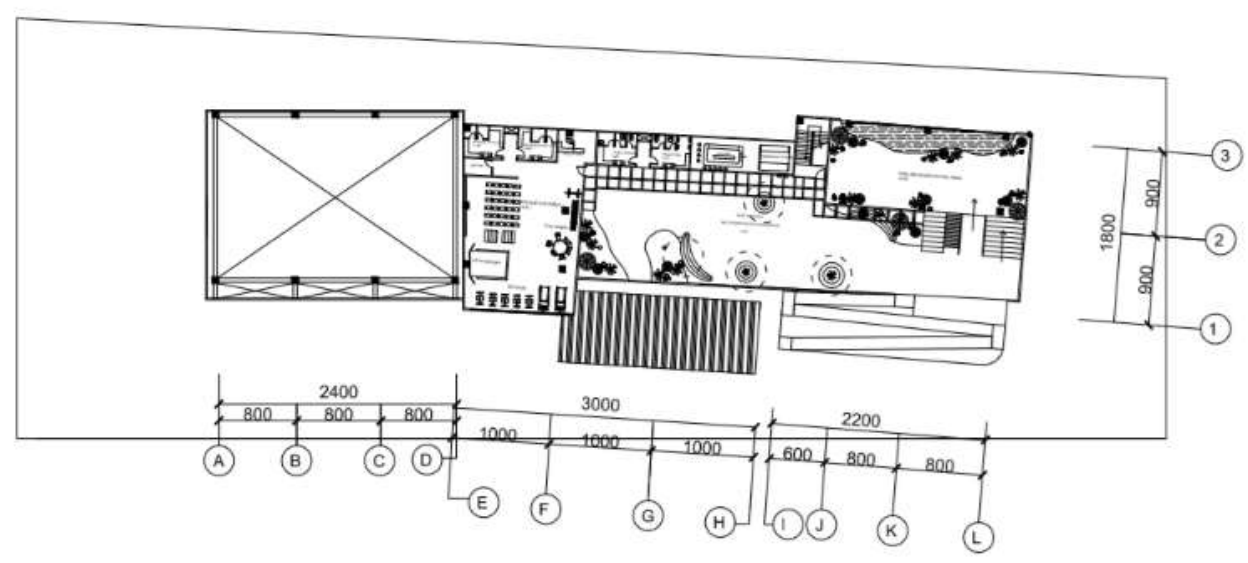

Gambar 9. Denah Lantai 2

Sumber: Penulis, 2020

Bentuk bangunan juga dibuat mengikuti bentuk dan axis bangunan-bangunan sekitarnya dengan bentuk dominan memiliki sudut atau persegi panjang agar memberi kesan kontekstual.

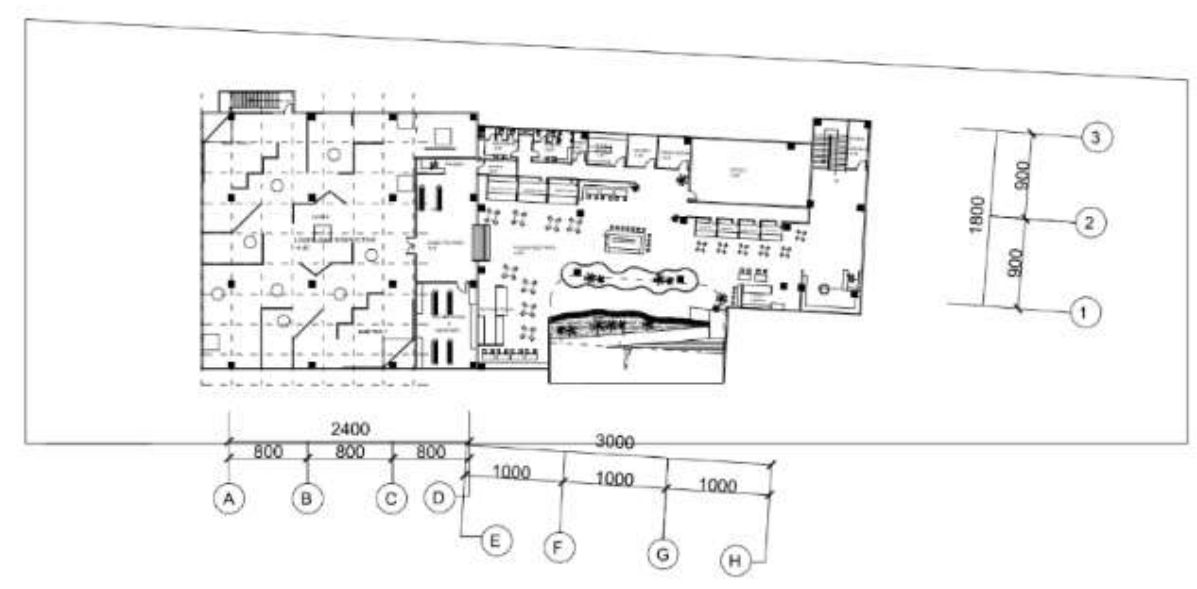

Gambar 10. Denah Lantai Basement

Sumber: Penulis, 2020

Penerapan konsep biophilic design terwujud pada lanskap lantai dasar dan penggunaan material di luar dan dalam bangunan, yang memberi bangunan berkesan bersatu dengan alam sekitar, dan terutama pada kegiatan berolahraga relaksasi dan kegiatan bersosialisasi di area plaza.

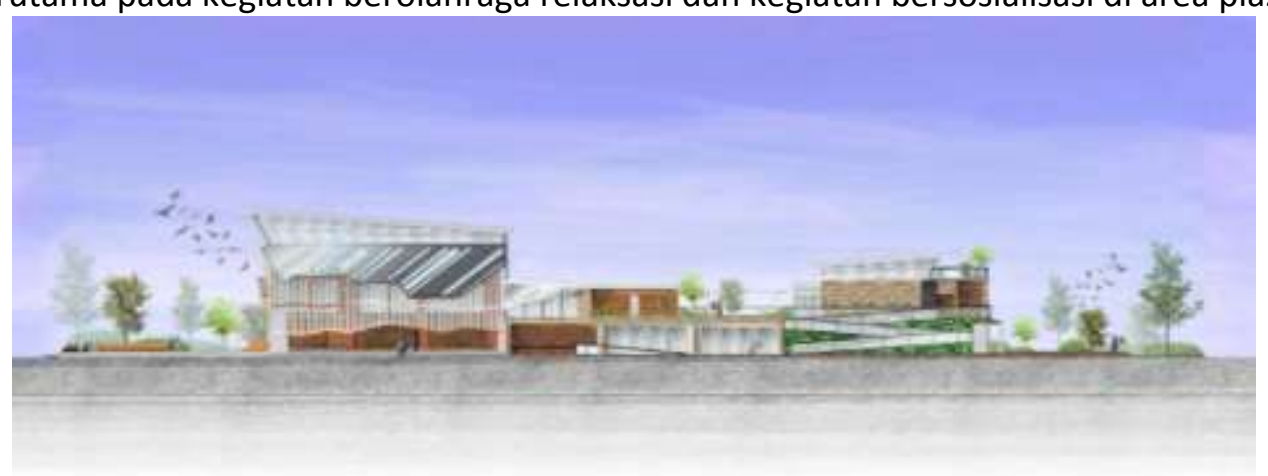

Gambar 11. Tampak Depan

Sumber: Penulis, 2020 


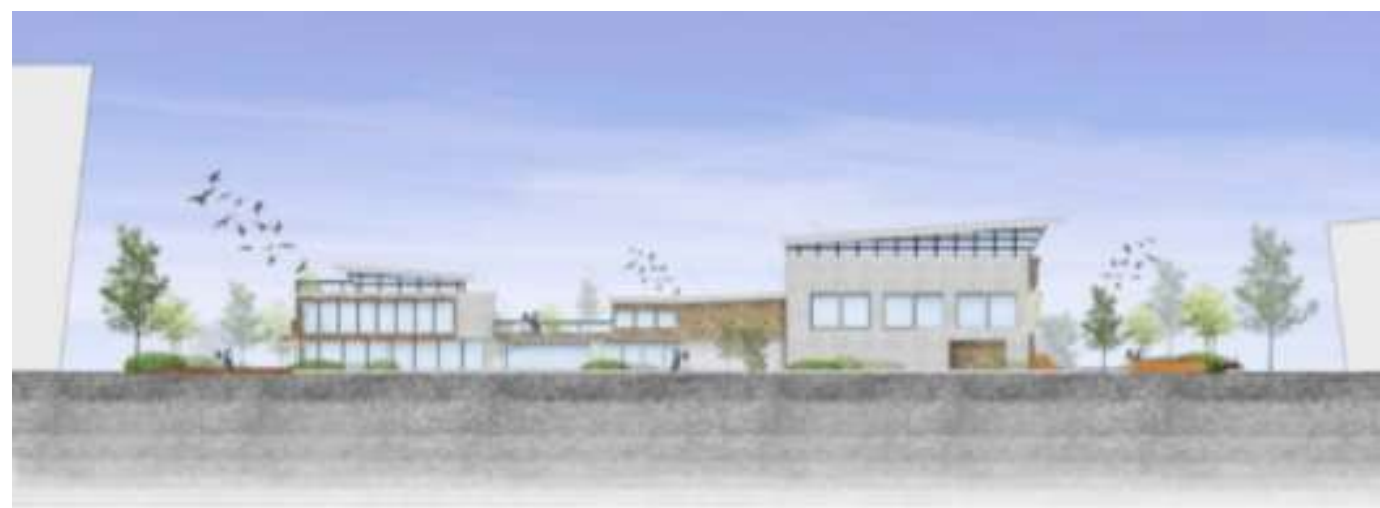

Gambar 12. Tampak Belakang

Sumber: Penulis, 2020

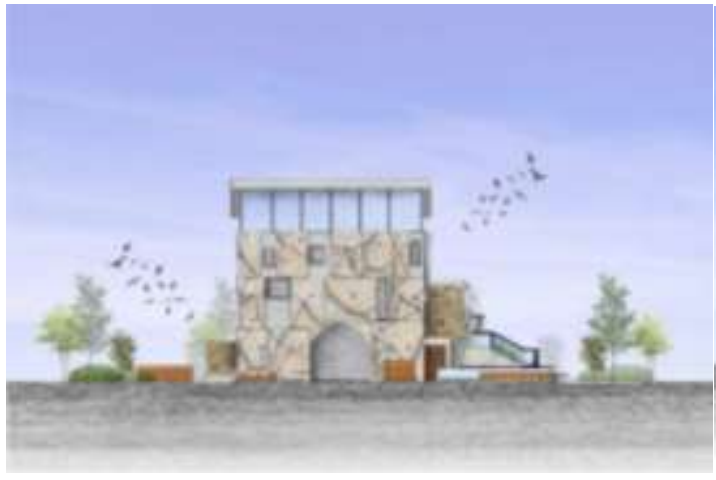

Gambar 13. Tampak Samping Kanan Sumber: Penulis, 2020

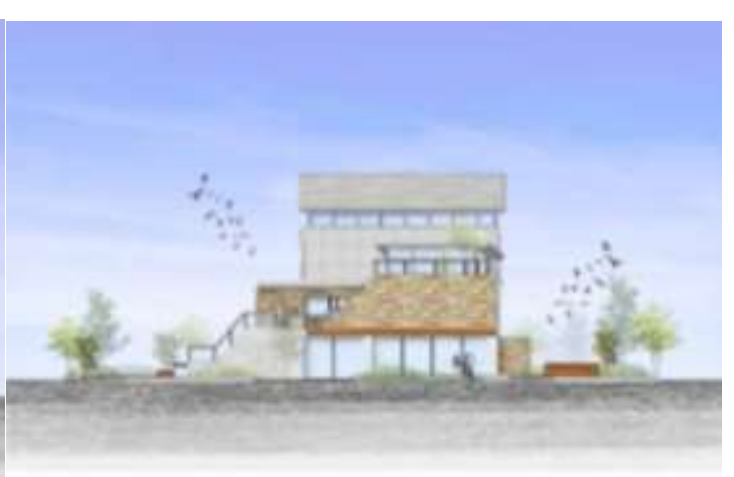

Gambar 14. Tampak Samping Kiri Sumber: Penulis, 2020

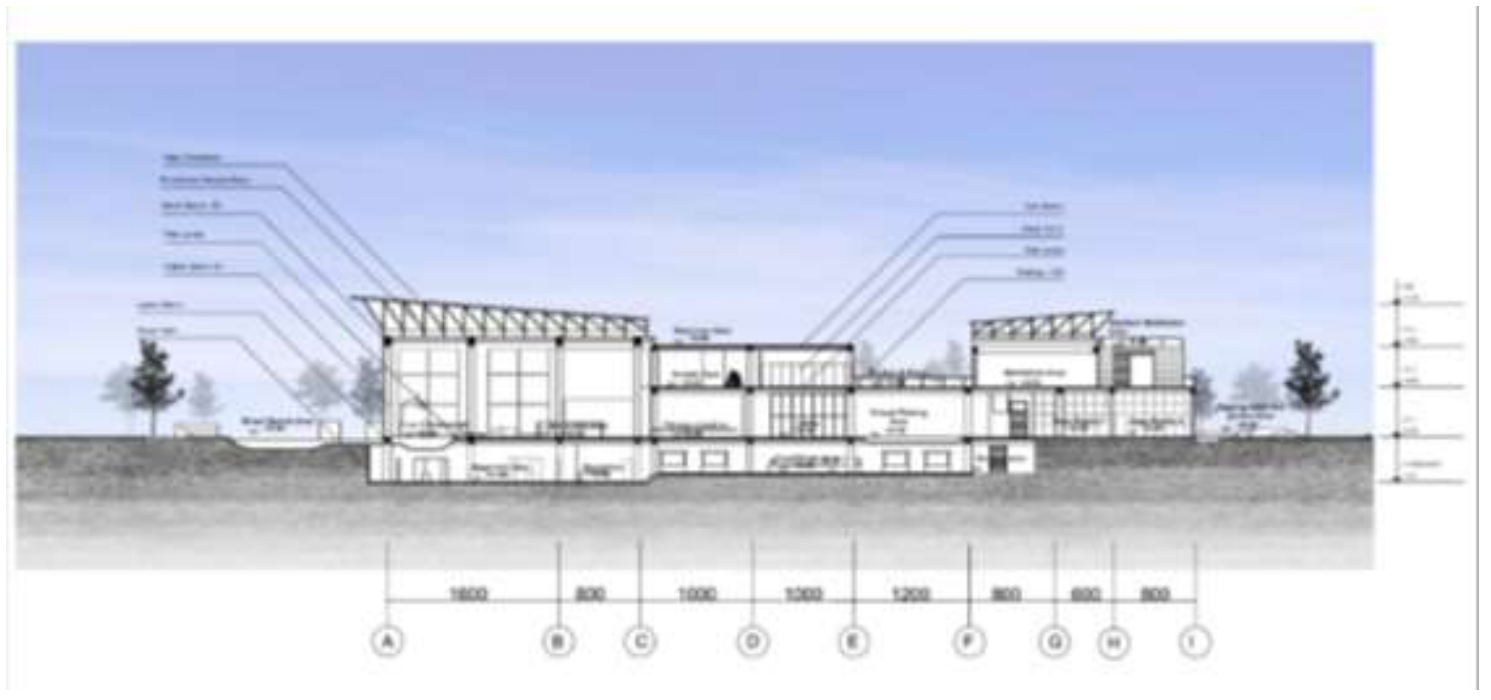

Gambar 15. Potongan A-A

Sumber: Penulis, 2020 


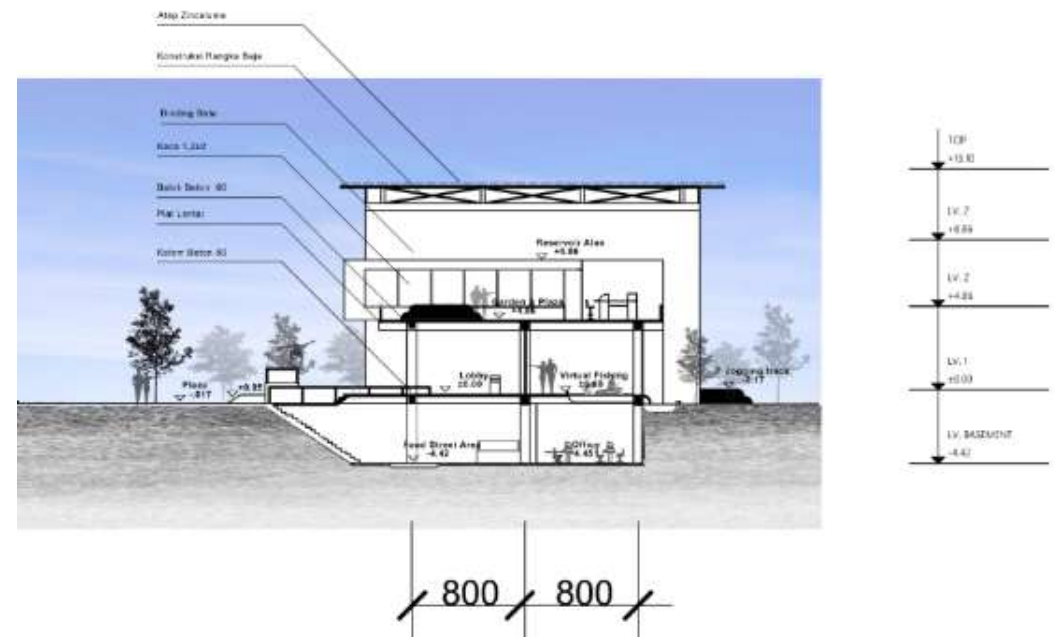

(A) (B) (C)

Gambar 16. Potongan B-B

Sumber: Penulis, 2020

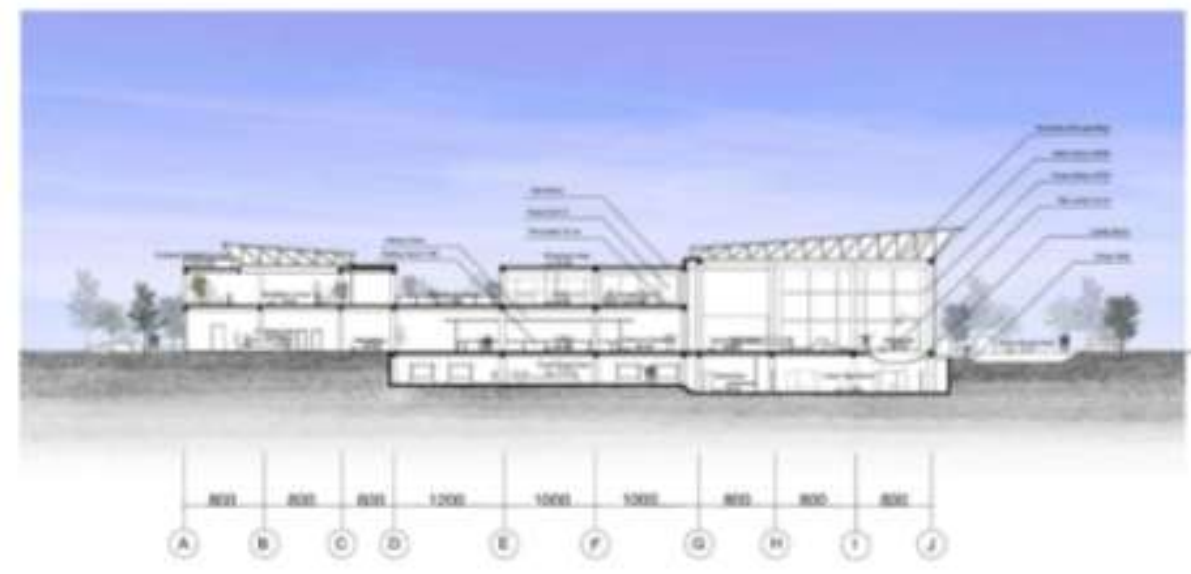

Gambar 17. Potongan C-C

Sumber: Penulis, 2020
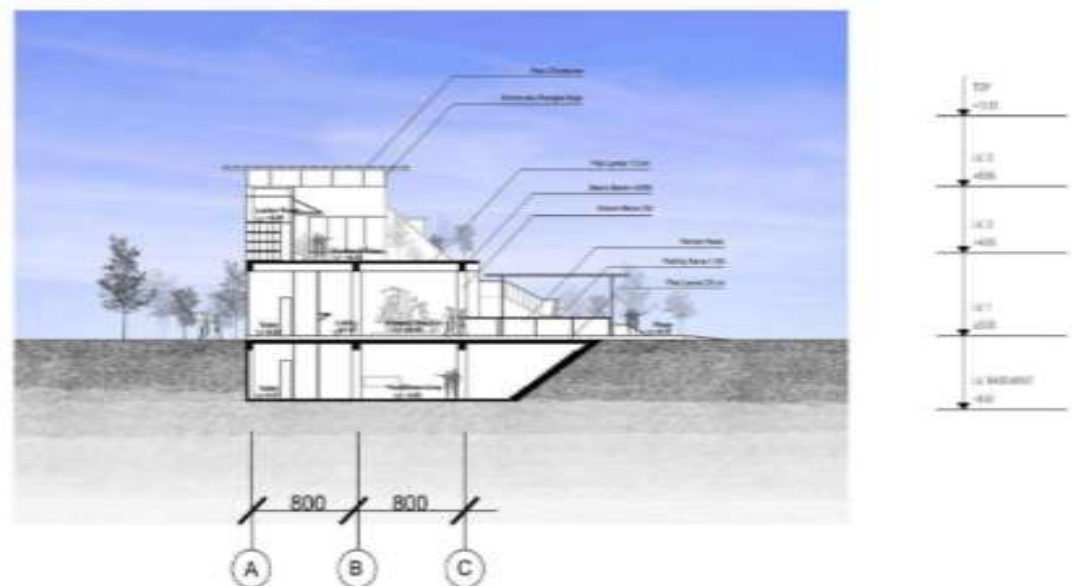

Gambar 18. Potongan D-D

Sumber: Penulis, 2020 


\section{KESIMPULAN DAN SARAN}

Kesehatan merupakan salah satu kebutuhan utama dalam masyarakat, salah satu prioritas yang dibutuhkan dalam masyarakat yaitu menjaga kesehatan. Proyek Sunter Permai Sports Park ini dapat berperan bagi masyarakat sebagai tempat untuk berkumpul dan berolahraga dengan gaya baru dan menyenangkan, dan merespon pada masalah kesehatan. Program yang dibuat juga merespon pada masalah kesehatan baik secara fisik maupun mental, mulai dari streetsports, relaxing sports, dan e-sports. Program juga dirancang untuk penyelesaian masalah diantara first place dan second place dalam masyarakat, dimana program hadir sebagai third place dengan kegiatan utama sports, yang memberi solusi bukan hanya kesehatan tapi juga sebagai tempat hiburan dan pelepas stress bagi masyarakat.

\section{Saran}

Saran untuk pengembangan studi dan desain kelanjutanya yaitu mempersiapkan lebih banyak studi preseden baik dari internet atau lapangan, untuk memperkuat konsep-konsep perancangan pada proyek; Menggunakan beragam cara untuk metode pengumpulan data-data selain interview dan analisis tapak langsung.

\section{REFERENSI}

Anderson, E. (2013). Effects of Exercise and Physical Activity on Anxiety. US National Library of Medicine.

Browning, W., D. (2014). 14 Patterns of Biophilic Design. TERRAPIN Bright Green, LLC. Heerwagen, Judith. (2008). Biophilic Design. Wiley Press.

International Journal of Interdisciplinary Research and Innovations, Vol. 2, Issue 4, pp: (139-156). Kecamatan Tanjung Priok dalam angka 2019. (2019). Diakses 16 Februari 2020, https://jakutkota.jakarta.bps.go.id/,

Nabkasorn, C. (2006). European Journal of Public Health, Volume 16, Issue 2, p. 179-184. Oxford University Press.

NewZoo. (2016). Diakses 15 Februari 2020. https://newzoo.com/insights/articles/the-newreality-for-mobile-gaming-the-vr-ar-opportunity/.

Oldenburg, R. (1999). The Great Good Place. Cambridge: Da Capro Press.

Riset Kesehatan Dasar, (2018). Hasil-riskesdas-2018. Diakses 16 Februari 2020, dari kemkes.com

Salingaros, N. (2006). Theory of Architecture: Pattern Languages, Geometrical Fundamentalism. Umbau-Verlag, Solingen.

Williams, F. (2017). The Nature Fix. W.W. Norton Company. 
